\title{
Passive Neutron Assay of Irradiated Negclear Fuels
}


LA-7645MS

Informal Report

(ISPO-47)

UC-15

Issued: February 1979

\section{Passive Neutron Assay of \\ Itradiated Nuclear Fuels}

S. T. Hsue

J. E. Stewart

K. Kaieda*

J. K. Halbig

J. R. Phillips

D. M. Lee

C. R. Hatcher

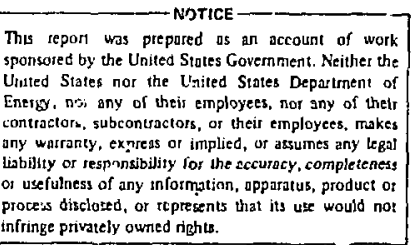

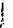

-Visiting Staft Member. Japan Atomic Energy Rerearch Institute, Tokai Research Establishment, Tokai-mura, Naka-gun, Ibaraki-ken, Japan.

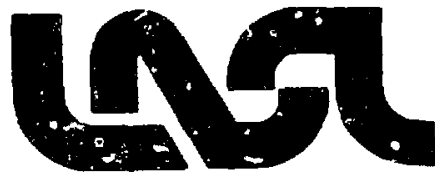


PASSIVE NEUTRON ASSAY OF IRRADIATED NUCLEAR FUELS

\author{
by
}

S. T. Hsue, J. E. Stewart, K. Kaieda, J. K. Halbig, J. R. Phillips, D. M. Lee, C. R. Hatcher

\title{
ABSTRACT
}

Passive neutron assay of irradiated nuclear fuel has been investigated by calculations and experiments as a simple, complementary technique to the gamma assay. From the calculations we have found that the neutron emission arises mainly from the curium isotopes, the neutrons exhibit very good penetrability of the assemblies, and the neutron multiplication is not affected by the burnup. From the experiments on BWR and PWR assemblies, we have found that the neutron emission rate is proportional to burnup raised to 3.4 power. Our investigations indicate that the passive neutron assay is a simple and useful technique to determine the consistency of burnups between assemblies.

\section{INTRODUCTION}

Nondestrucitive assay (NDA) methods for the determination of the burnup and cooling times of irradiated nuclear fuels are needed to safeguard against diversion of fissile materials to weapon use. Because irradiated fuels represent a possible source of plutonium, it is esseritial that the International Atomic Energy Agency (IAEA) have a measurement capability for effective international safeguards. For easy implementation the prefierred NDA method should use simple, portable equipment that can be carried from site to site for rapid and reasonably accurate assays. 
Gamma-spectroscopy has been investigated as a measurement method for determining nondestructively the burnup and sooling time of irradiated cuels. ${ }^{1-4}$ the measurement is usually performed in a hot cell or in a cooling pond. The method is based on measurement of the concentrations of radioactive burnup monitors $\left({ }^{95} \mathrm{Zr}, \quad{ }^{137} \mathrm{Cs}\right.$, or $\left.{ }^{144} \mathrm{Ce}-{ }^{144} \mathrm{Pr}\right)$ or, in recent years, the activity ratios $\left({ }^{134} \mathrm{Cs} /{ }^{137} \mathrm{Cs}\right.$ or $\left.{ }^{154} \mathrm{Eu} /{ }^{137} \mathrm{Cs}\right)$. The problems related with gamma-spectroscopic measurements have recently been reviewed. ${ }^{1-3}$ The major problems are the fission products (or their precursors) may migrate at high fuel temperature $\left({ }^{106} \mathrm{Fu}-{ }^{106} \mathrm{Rh},{ }^{134} \mathrm{Cs}\right.$, and $\left.{ }^{137} \mathrm{Cs}\right)$; the intensities of gamma rays from the fission products in the interiors of assemblies are substantially attenuated by the reiatively dense fuel rods (density $\sim 1 \mathrm{~J} \mathrm{~g} / \mathrm{cm}^{3}$ ); these activity ratios are sensitive to the epithermal-to-thermal flux ratio in addition to the fuel burnup. Burnup measurements cannot be performed by gamma assay on fuels shortly after discharge because the gamma activity is dominated by relatively short-lived isotopes (e.g., 140 La), reflective of recent reactor power level. Gamma-spectroscopic measurement also requires high-resolution germanium detector and multichannel analyzer (MCA), both of which necessitate welltrained personnel to obtain meaningful results. Though it is foreseeable that MCA with automatic features can be developed, thus mirimizing the need for comprehensive training of the operator, $\tilde{a}_{\text {c }}$ basic problem of the gamma assay method remains--it is only sensitive to the outer layers of rods of a fuel assembly. An al.ternative NDA method more sensitive to interior rods of an assembly is highly desirable for spent fuel inspection.

In addition to the varjous gamma rays, irradiated fuels also emit neutrons. Neutrons are less subject to self-absorption in the fuel assembly than are gamma rays. Passive neutron assay has been identified as a potentially useful inspection assay method of spent fuel both by the recent review 2,3 and in the IAEA Advisory Group Meeting. 4 
At the Los Alamos Scientific Laboratory (LASL) we have performed calculations and experiments to investigate the merits of passive neutron assay. From the calculations we have found that the neutron emission arises mainiy from the curium isotopes, 5 and that the neutrons exhibit very good penetrability of the assemblies. ${ }^{6}$ From the experiments on boiling water reactor (BWR) and pressurized water reactor (PWR) assemblies, 7 we have found that the neutron emission rate is proportional to burnup raised to $\sim 3.4$ power. This report will summarize our findings with passive neutron assay.

\section{ORIGINS OF THE PASSIVE NEUT"RONS}

In a spent fuel assembly, neutron emission arises from spontaneous fissioning of the even isotopes of plutonium and curium and from the $(\alpha, n)$ reaction in oxide arising from the alpha emission of the various isotopes of plutonium, americium, and curium. Figure 1 shows the major pathways of production of the transuranium isotopes in fuels irradiated in light water reactors (LWR). While it is possible to calculate the buildup of the transuranium isotopes, the uncertainty of such a calculation would be large because the neutron capture cross sections of some of these isotopes are not well established.

The following calculations are based on the results of a postirradiation examination study on Trino Vercellese reactor fuel. 8 In this study, which was done in Italy in 1976, the burnups of each of the fuel samples were determined by massspeutrometric measurements of ${ }^{148} \mathrm{Nd}$. The uranium, plutonium and americium isotopic concentrations were determined by mass spectrometry with typical precision of better than $0.5 \%$. The curium isotopic contents were determined by means of alphaspectrometry measurement. The standard deviations of the measurements of the curium concentrations are better than $5 \%$. All the isotopic compositions were referred to reactor shut-

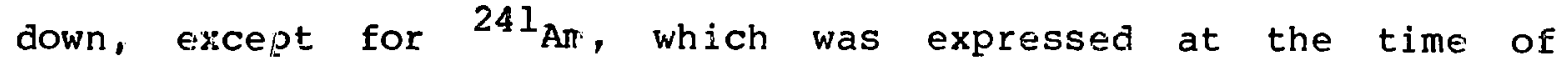
measuremen:. 
To calculate the passive neutron emission rate arising from the spontaneous fission and $\left(\alpha_{0} n\right)$ reaction in oxide, we used the nuclear data information shown in Table I. $^{9}$ Using the isotopic composition of the fuel samples as determined by destructive analysis, we calculated the neutron enission rate at discharge and at subsequent cooling time for burnups ranging between 13000 and 27000 MWD/MTU. Figure 2 shows the calculated neutron emission rate for a 12859 MWD/MTU burnup fuel sample; Fig. 3 shows the neutron yield for a $26 \quad 884$ MWD/MTU burnup fue1. The percentage contributions from the various fissionable isotopes to passive neutron emission rates are shown in Table II. Curium isotopes are the main contributors of the passive neutrons for burnups that exceed $15000 \mathrm{MWD} / \mathrm{MTU}$, accounting for at least 70 \% of the neucrons up to a cooling time of seven years. For cooling times of less than two years, the two curium isotopes dominate the neutron emission (greater than 708) with ${ }^{242} \mathrm{Cm}$ the major contributor at short cooling times. Only

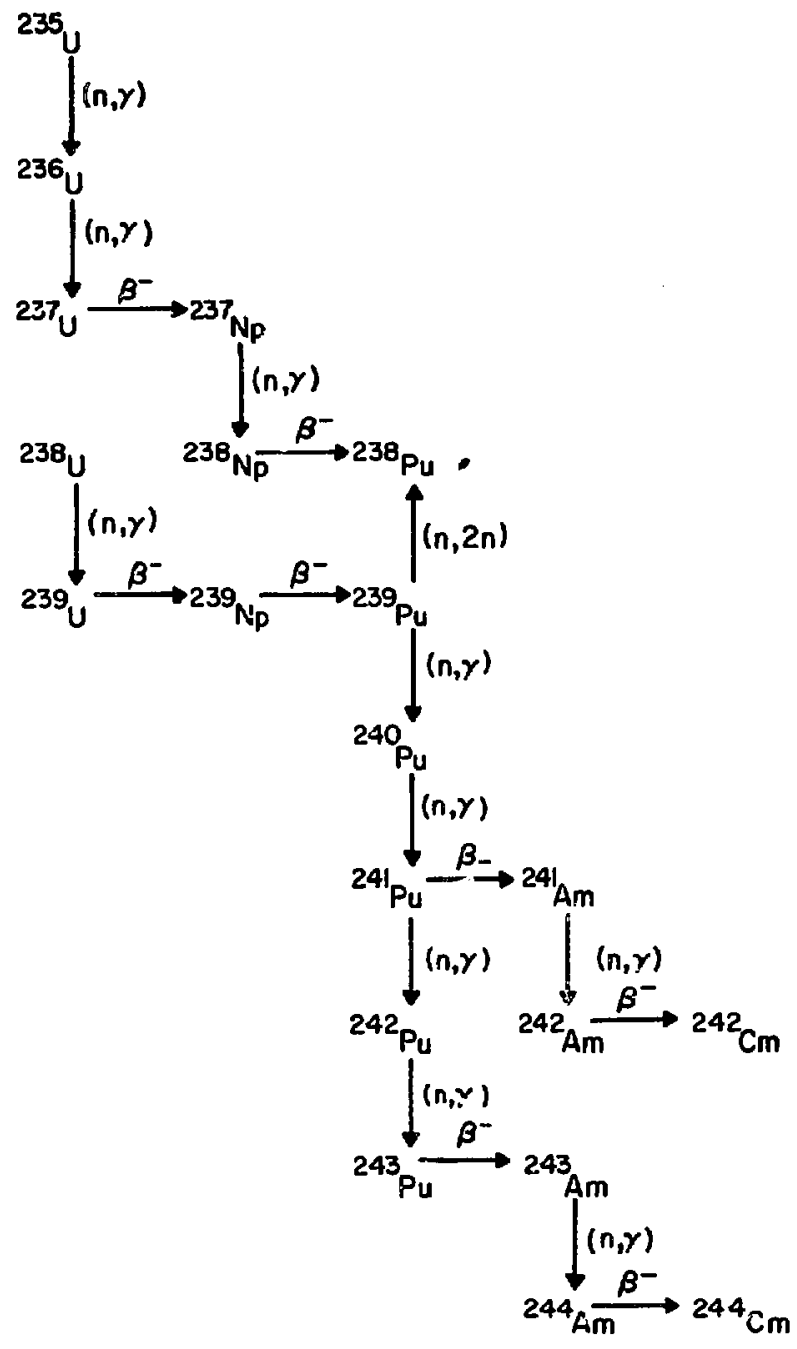

Fig. 1 .

Major pathways of production of transuranium isotopes. 
SPONTANEOUS FISSION AND ALPHA-INDUCED NEUTRON YIELD

\begin{tabular}{|c|c|c|c|c|}
\hline \multirow[b]{2}{*}{ Source } & \multirow{2}{*}{$\begin{array}{c}\text { Total } \\
\text { Half-life } \\
\text { (years) }\end{array}$} & \multicolumn{3}{|c|}{$\frac{\text { Yield neutron }}{\mathrm{g} \mathrm{s}}$} \\
\hline & & $\begin{array}{c}\text { Spontaneous } \\
\text { fission }\end{array}$ & $\begin{array}{c}(\alpha, n) \\
\text { in oxide } \\
\end{array}$ & Total \\
\hline${ }^{235} \mathrm{v}$ & $7.10 \times 10^{8}$ & $5.12 \times 10^{-4}$ & $1.11 \times 10^{-3}$ & $1.62 \times 10^{-3}$ \\
\hline $238_{\mathrm{U}}$ & $4.51 \times 10^{9}$ & $1.14 \times 10^{-2}$ & $1.33 \times 10^{-4}$ & $1.15 \times 10^{-2}$ \\
\hline 238 & $8.78 \times 10^{1}$ & $2.51 \times 10^{3}$ & $1.84 \times 10^{4}$ & $2.09 \times 10^{4}$ \\
\hline 239 & $2.44 \times 10^{5}$ & $2.16 \times 10^{-2}$ & $5.38 \times 10^{1}$ & $5.38 \times 10^{1}$ \\
\hline & $6.55 \times 10^{3}$ & $0.14 \times 10^{2}$ & $2.01 \times 1.0^{2}$ & $1.11 \times 10^{3}$ \\
\hline 24 & $1.47 \times 10^{1}$ & $1.10 \times 10^{-2}$ & 1.96 & 1.97 \\
\hline $242 \mathrm{Pu}$ & $3.87 \times 10^{5}$ & $1.68 \times 10^{3}$ & 2.87 & $1.68 \times 10^{3}$ \\
\hline $24 I_{A m}$ & $4.33 \times 10^{2}$ & $5.79 \times 10^{-1}$ & $3.64 \times 10^{3}$ & $3.64 \times 10^{3}$ \\
\hline $242 \mathrm{~cm}$ & $4.46 \times 10^{-1}$ & $2.13 \times 10^{7}$ & $4.75 \times 10^{6}$ & $2.60 \times 10^{7}$ \\
\hline${ }^{244} \mathrm{~cm}$ & $1.31 \times 10^{1}$ & $1.10 \times 10^{7}$ & $1.03 \times 10^{5}$ & $1.12 \times 10^{7}$ \\
\hline
\end{tabular}

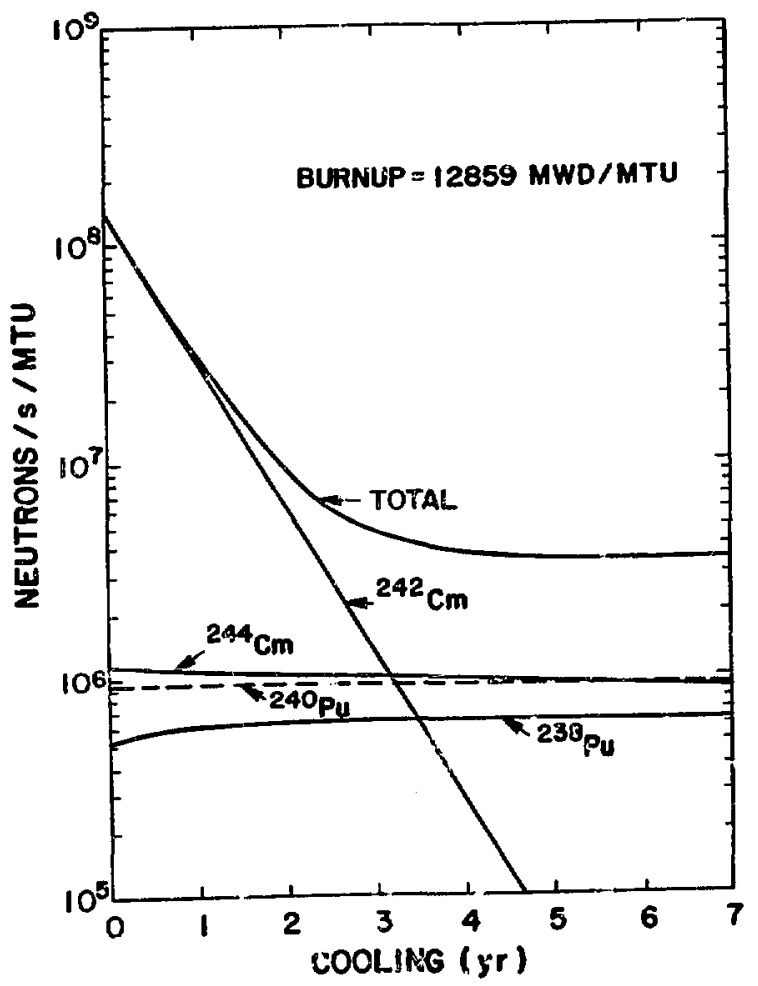

Fig. 2. Neutrons per second from $238 \mathrm{Pu}$, ${ }_{240} \mathrm{Pu},{ }_{242} \mathrm{Cm}$, and ${ }^{24} \mathrm{Cm}$ isotopes at a burnup of 12859 MWD/MTU. The total includes contributions from the other uranium, plutonium, and americium isotopes of the Trino reactor fuel. 
TABLE II

PERCENTAGE CONTRIBUTION TO PASSTVE NEUTRON EMISSION

RATE FROM THE FISSIONABLE ISOTORES

\begin{tabular}{|c|c|c|c|c|c|c|c|c|c|c|}
\hline $\begin{array}{l}\text { Cooling } \\
\text { lyears } \\
\mathrm{BU}=12859\end{array}$ & $\begin{array}{l}\text { Time } 235 \mathrm{U} \\
\text { MWD/MTU }\end{array}$ & $238 U$ & $238_{\mathrm{Pu}}$ & $239 \mathrm{Pu}$ & $240_{\mathrm{Pu}}$ & $241 \mathrm{Pu}$ & $242 \mathrm{Pu}$ & $242 \mathrm{~cm}$ & $244 \mathrm{~cm}$ & $241_{\mathrm{Am}}$ \\
\hline $\begin{array}{l}0 \\
1 \\
2 \\
3 \\
5 \\
7\end{array}$ & $\begin{array}{l}2.3-5 * 1 \\
9.9-5 \\
3.3-4 \\
6.7-4 \\
9.0-4 \\
9.0-4\end{array}$ & $\begin{array}{l}8 \cdot 0-3 \\
3 \cdot 5-2 \\
1 \cdot 2-1 \\
2 \cdot 3-1 \\
3 \cdot 1-1 \\
3 \cdot 2-1\end{array}$ & $\begin{array}{l}3.8-1 \\
1.9 \\
6.6 \\
13.4 \\
17.9 \\
18.0\end{array}$ & $\begin{array}{l}1.8-1 \\
7.7-1 \\
2.6 \\
5.2 \\
7.0 \\
7.0\end{array}$ & $\begin{array}{l}6.8-1 \\
2.9 \\
9.9 \\
19.8 \\
26.5 \\
26.7\end{array}$ & $\begin{array}{l}5 \cdot 7-4 \\
2 \cdot 4-3 \\
7 \cdot 6-3 \\
1 \cdot 5-2 \\
1 \cdot 8-2 \\
1 \cdot 6-2\end{array}$ & $\begin{array}{l}5.6-3 \\
2.4-1 \\
3.2-1 \\
1.6 \\
2.2 \\
2.2\end{array}$ & $\begin{array}{l}97.6 \\
89.5 \\
64.0 \\
27.2 \\
1.6 \\
7.3-2\end{array}$ & $\begin{array}{l}8.3-1 \\
3.5 \\
11.3 \\
21.8 \\
27.0 \\
25.1\end{array}$ & $\begin{array}{l}2.2-1 \\
1.2 \\
4.6 \\
10.6 \\
17.4 \\
20.5\end{array}$ \\
\hline $\begin{array}{c}\mathrm{BU}=15170 \\
0 \\
1 \\
2 \\
3 \\
5 \\
7\end{array}$ & $\begin{array}{c}\text { MWD/MTU } \\
1.4-5 \\
5.3-5 \\
1.4-4 \\
2.1-4 \\
2.5-4 \\
2.6-4\end{array}$ & $\begin{array}{l}53 \cdot-3 \\
2 \cdot 0-2 \\
5 \cdot 3-2 \\
8 \cdot 1-2 \\
9 \cdot 7-2 \\
1 \cdot 0-1\end{array}$ & $\begin{array}{l}3.5-1 \\
1.6 \\
4.2 \\
6.5 \\
7.8 \\
8.2\end{array}$ & $\begin{array}{l}1.2-1 \\
4.7-1 \\
1.2 \\
1.8 \\
2.2 \\
2.3\end{array}$ & $\begin{array}{l}5.4-1 \\
2.1 \\
5.4 \\
8.3 \\
10.0 \\
10.5\end{array}$ & $\begin{array}{l}4 \cdot 9-4 \\
1.8-3 \\
4 \cdot 4-3 \\
6.4-3 \\
7.0-3 \\
6.7-3\end{array}$ & $\begin{array}{l}5 \cdot 9-2 \\
2 \cdot 3-1 \\
5 \cdot 9-1 \\
9 \cdot 0-1 \\
1 \cdot 1 \\
1 \cdot 1\end{array}$ & $\begin{array}{l}94.0 \\
77.1 \\
42.2 \\
13.6 \\
7.3-1 \\
3.4-2\end{array}$ & $\begin{array}{l}4.7 \\
17.7 \\
44.7 \\
64.7 \\
71.9 \\
70.0\end{array}$ & $\begin{array}{l}1.5-1 \\
7.3-1 \\
2.3 \\
4.0 \\
6.1 \\
7.7\end{array}$ \\
\hline $\begin{array}{c}\mathrm{BU}=20602 \\
0 \\
1 \\
2 \\
3 \\
5 \\
7\end{array}$ & $\begin{array}{c}\text { MWD/MTU } \\
4.4-6 \\
1.5-5 \\
3.0-5 \\
4.0-5 \\
4.6-5 \\
4.9-5\end{array}$ & $\begin{array}{l}2 \cdot 1-3 \\
7 \cdot 0-3 \\
1.9-2 \\
1 \cdot 9-2 \\
2 \cdot 1-2 \\
2.3-2\end{array}$ & $\begin{array}{l}3.2-1 \\
1.3 \\
2.7 \\
3.5 \\
4.0 \\
4.3\end{array}$ & $\begin{array}{l}5.8-2 \\
2 \cdot 0-1 \\
4 \cdot 0-1 \\
5 \cdot 3-1 \\
6 \cdot 0-1 \\
6.5-1\end{array}$ & $\begin{array}{l}3.2-.1 \\
1.1 \\
2.2 \\
2.9 \\
3.3 \\
3.5\end{array}$ & $\begin{array}{l}3 \cdot 3-4 \\
1 \cdot 1-3 \\
2 \cdot 1-3 \\
2 \cdot 6-3 \\
2 \cdot 7-3 \\
2.6-3\end{array}$ & $\begin{array}{l}5 \cdot 6-2 \\
1 \cdot 9-1 \\
3 \cdot 8-1 \\
5 \cdot 0-1 \\
5 \cdot 8-1 \\
6.2-1\end{array}$ & $\begin{array}{l}B 8.8 \\
63.3 \\
27.3 \\
7.6 \\
3.9-1 \\
1.9-2\end{array}$ & $\begin{array}{l}10.3 \\
33.5 \\
65.8 \\
83.1 \\
88.5 \\
87.6\end{array}$ & $\begin{array}{l}1.2-1 \\
5.0-1 \\
1.2 \\
1.8 \\
2.5 \\
3.2\end{array}$ \\
\hline $\begin{array}{c}\mathrm{BU}=26884 \\
0 \\
1 \\
2 \\
3 \\
5 \\
7\end{array}$ & $\begin{array}{c}\text { MND,MTU } \\
1.8-6 \\
5.3-6 \\
9.2-6 \\
1.1-5 \\
1.3-5 \\
1.3-5\end{array}$ & $\begin{array}{l}1.2-3 \\
3 \cdot 4-3 \\
6.0-3 \\
7 \cdot 3-3 \\
8.2-3 \\
8 \cdot 8-3\end{array}$ & $\begin{array}{l}2.9-1 \\
1.0 \\
1.8 \\
2.2 \\
2.5 \\
2.7\end{array}$ & $\begin{array}{l}3.2-2 \\
9.4-2 \\
1.6-1 \\
2.0-1 \\
2.2-1 \\
2.4-1\end{array}$ & $\begin{array}{l}2.2-1 \\
6.6-1 \\
1.1 \\
1.4 \\
1.6 \\
1.7\end{array}$ & $\begin{array}{l}2.4-4 \\
6.8-4 \\
1.1-3 \\
1.3-3 \\
1.3-3 \\
1.3-3\end{array}$ & $\begin{array}{l}6 \cdot 1-2 \\
1.8-1 \\
3 \cdot 1-1 \\
3 \cdot 8-1 \\
4 \cdot 3-1 \\
4.6-1\end{array}$ & $\begin{array}{l}83.1 \\
51.9 \\
19.1 \\
4.9 \\
2.5-1 \\
1.2-2\end{array}$ & $\begin{array}{l}16.2 \\
45.8 \\
76.8 \\
89.9 \\
93.7 \\
93.2\end{array}$ & $\begin{array}{l}9.7-2 \\
3.4-1 \\
7.0-1 \\
9.7-1 \\
1.3 \\
1.7\end{array}$ \\
\hline
\end{tabular}

for low burnup (less than 15000 MWD/MTU) and for long cooling times (greater than two years) are the contributions from the $P u$ isotopes significant to the neutron emission rate. In the $242 \mathrm{~cm}$ and ${ }^{244} \mathrm{~cm}$ decay, spontaneous fission is the major source of the passive neutron emission (see Table $I$ ).

If all the assemblies being verified have cooling times longer than two years, then cooling time corrections can be neglected because most of the ${ }^{242} \mathrm{~cm}$ activity ( $T_{\frac{T_{2}}{2}}=163$ days) will have decayed away, and the other neutron emitting isotopes 


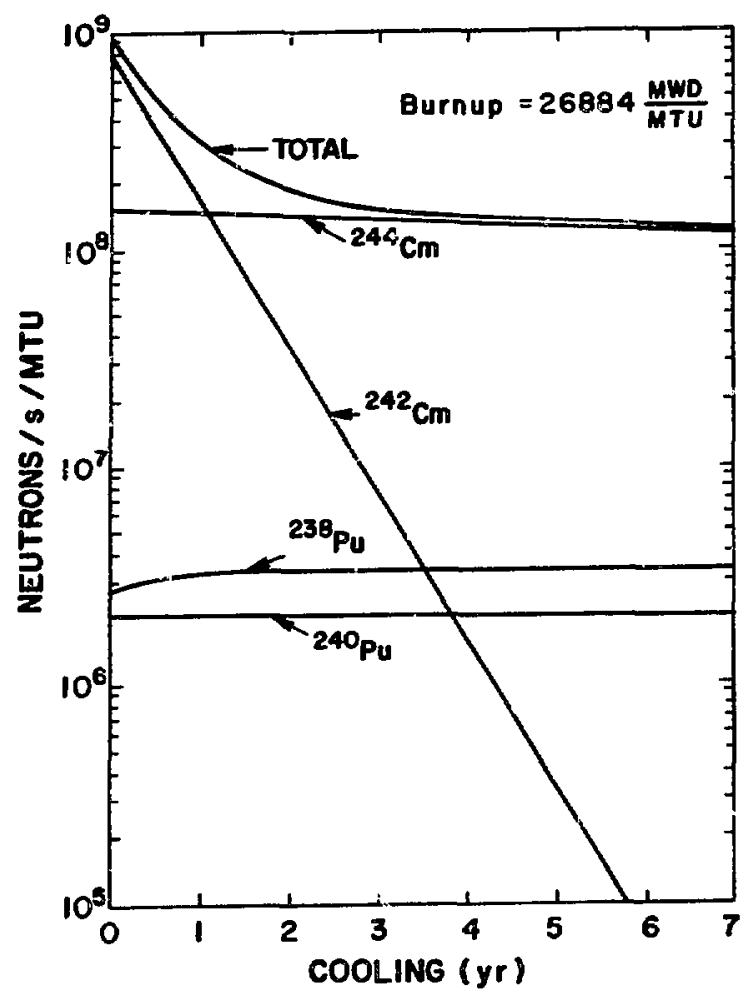

Fig. 3. Neutrons per second from ${ }^{23}{ }^{3} \mathrm{Pu}$, ${ }^{240} \mathrm{Pu},{ }^{243} \mathrm{Cm}$, and $24{ }^{4} \mathrm{~cm}$ isotopes at a burnup of 26884 MWD/MTU. The total includes contributions from the other uranium, plutonium, and americium isotopes of the Trino reactor fuel.

have half-lives longer thail 14 years. For cooling times less than six months (burnup less than 27000 MWD/MTU), the doriinant neutron emission source decays with the 163 day half-life. Between these two limits, the neutron emission rate depends on the burnup and cooling times.

These calculations indicate that passive neutron emission from irradiated fuels depends on the accumulation of the ${ }^{242} \mathrm{~cm}$ and ${ }^{244} \mathrm{Cn}$ isotopes, which in turn depends on the burnup.

\section{PROPERTIES OF PASSIVE NEUTRON ASSAY}

For inspection purposes, the spent fuels normally will be assayed as whole assemblies submerged in water. To explore the properties of passive neutron assay such as response versus distance, assay penetrability, and the multiplication effect, we performed the following calculations.

A Monte Carlo transport code, MCND, 10 was used for the calculations. A Trino reactor spent fuel assembly was mocked up as shown in Fig. 4. For ease in computation, the assembly was 
Fig. 4.

Cross section of one-eighth of a Trino assembly; $A B$ and $C D$ are neutron reflective surfaces. Together they simulate the complete spent fuel assembly.

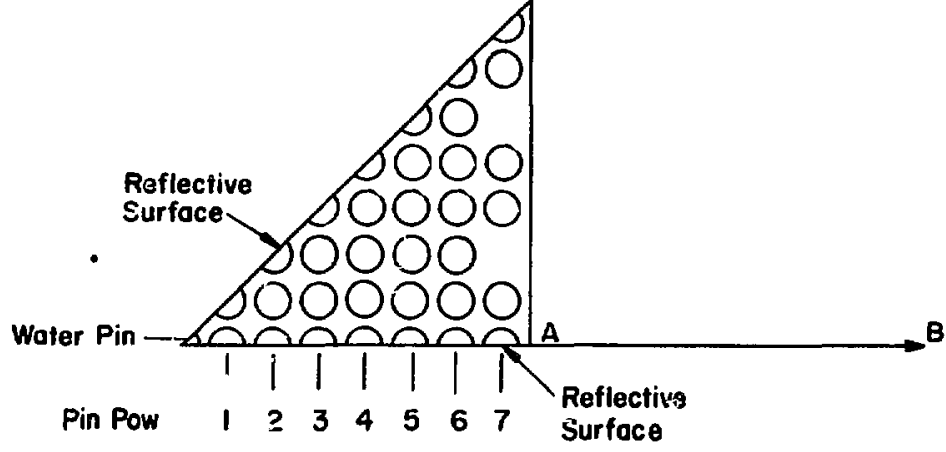

assumed to be infinite in length, and the fuel pin cladding was mixed with the fuel. These assumptions were not expected to affect results significantly. The neutron sources for different burnups within the fuel rods were taken from the results of the previous calculations in Sec. II and based on postirradiation destructive examinations. The neutron sources in the assembly were generated assuming a cooling time of one year. A water temperature of $54^{\circ} \mathrm{C}$ was assumed.

A. Neutron Response Versus Distance

The purpose of this calculation is to optimize the location of the neutron detector and to determine the sensitivity of passive neutron assay to variation in detector-to-source distances.

Figures 5 and - represent spatial flux distributions (at the assembly midplane) in water outside one assembly. The burnup value chosen $f$ or the plot is $20602 \mathrm{MWD} / \mathrm{MTU}$. In Fig. 5, distance is measured along line $A B$ (midplane normal as referred to in $F i g$. 4). In Fig. 6, distance is along line CD (midplane diagonal).

In general, the midpiane normal flux is higher than the midplane diagonal flux at the same distance from the assembly surface. Notice that for the thermal neutrons lenergy les 3 than 
$\left.5 \times 10^{-7} \mathrm{MeV}\right)$ the flux exhibits a smaller slope through the region $0-3 \mathrm{~cm}$ than in the region further from the assembly (see Fig. 5) due to the slowing down of fast neutrons. A thermal neutron detector so positioned wich respect to the assembly can minimize the effect of distance variations as well as maximize the neutron response.

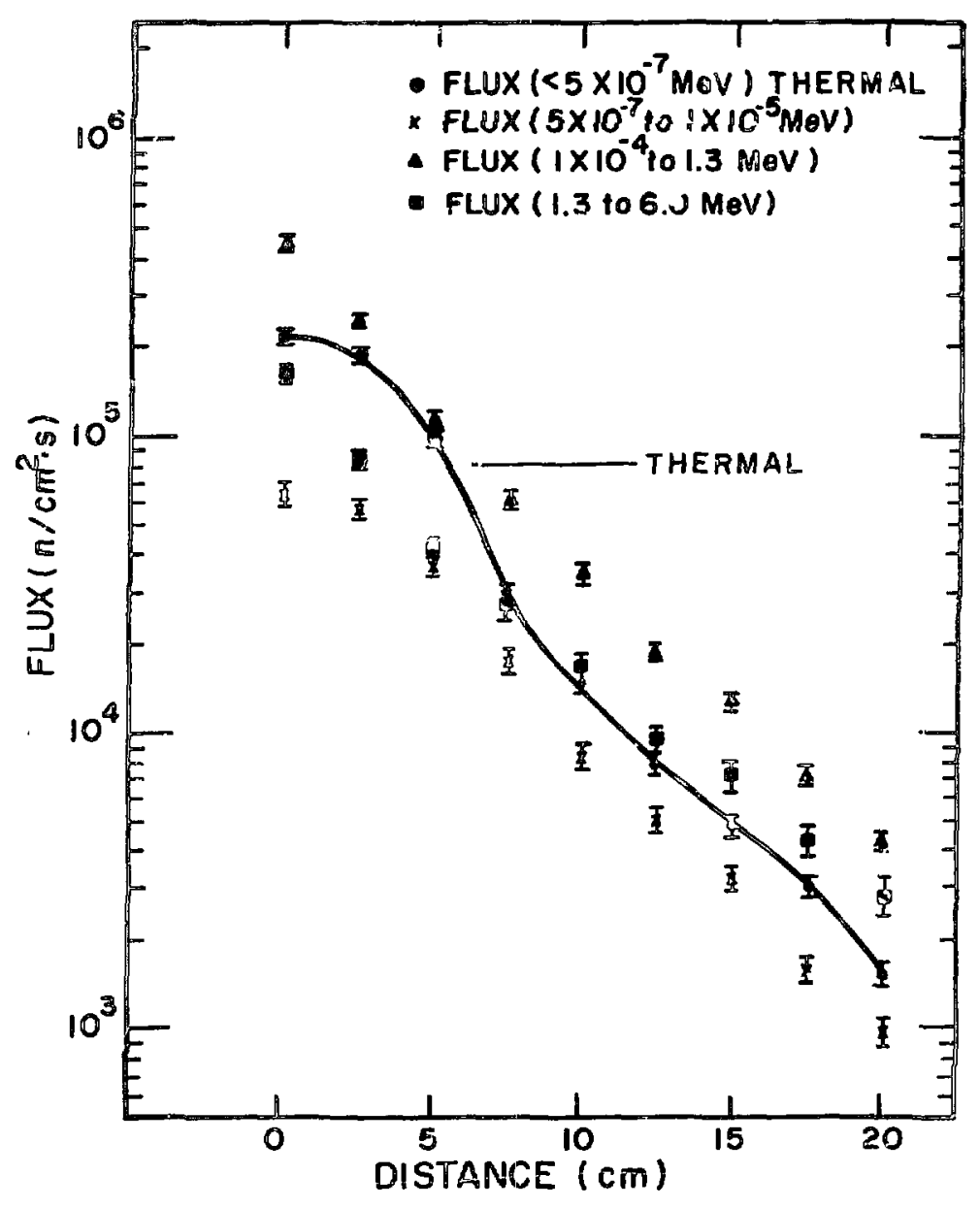

Fig. 5.

Flux along midplane normal from the assembly. 
B. Assay Penetrability

The purpose of this calculation is to investigate the spatial distribution of the importance of fuel pins in contributing to the detector signal. Or, in other words, how well does a neutron from inside the assembly escape from the assembly? An intermediate burnup level (20 602 MWD/MTU) assembly was chosen.

In the first calculation, source neutrons were started uniformly in the volume of the first fuel pin row; in the second calculation rows 1 through 3 (see Fig. 4 for the definition of

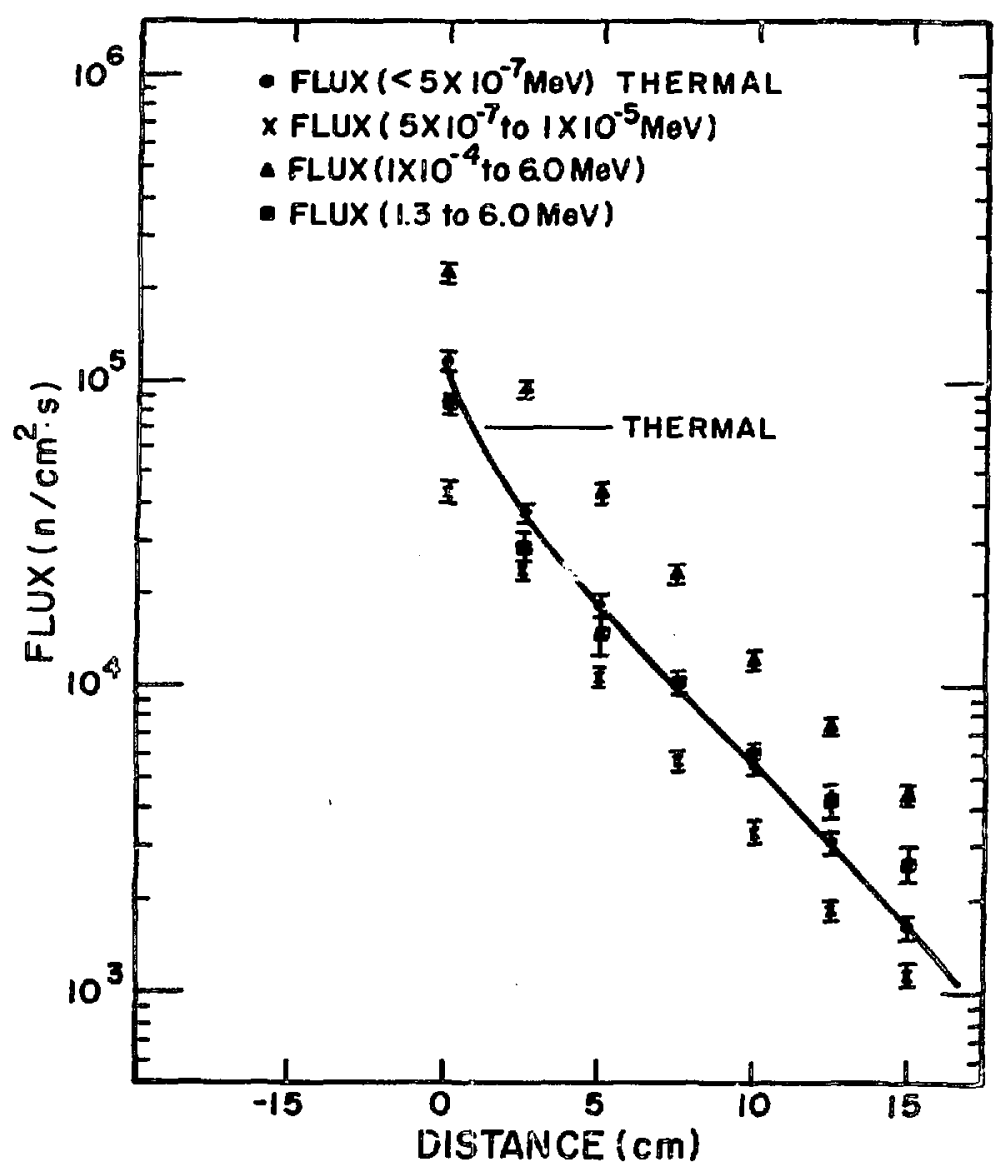

Fig. 6 .

Flux along midplane diagonal from the assembly. 
row): in the third calculation, rows 1 through 5; and in the fourth calculation, rows 1 through 7 (all fuel pins). Note that the first fuel pin row is actually the second row of pins, the first being a central water pin. These calculations allowed the determination of the relative flux contribution of various combin:tions of fuel fin rows. The results of the calculation are summarized in Table III. In this table the flux contribution per pin from all the fuel pins is normalized to one. If the flux contribution per pin is greater than one, that means these rows of fuel pins will make an above-average contribution to the signals of passive neutron assay. The standard deviation (S.D.) in Table III is a measure of the uniformity of flux contribution from the various rows of fuel pins, the smaller the standard deviation, the more uniform the contributions.

The results indicate a relatively uniform flux contribution within the calculational precision of about 8\%. Thus, passive neutron assay "sees" all the fuel pins about equally well. The reason that the neutron signals originating in the inner fuel pin rows can penetrate the assembly is because the source neutrons from the inner rows slow down in the water and induce fissioning in the outer fuel rows. The neutrons from the induced fissions can ther penetrate the assembly. In this respect the passive neutron assay is significartly different from the gamma assay, which detects signals from the outer layers of the assembly.

C. Multiplication Effect

Next, the neutron multiplication effect was examined. While the $\mathrm{Cm}$ isotopes (the origin of most of the passive neutrons) within the fuel rods may be proportional to burnup as indicated in the postirradiation examination, ${ }^{8}$ the passive neutron assay response may be different due to neutron multiplication dependence on burnup.

In this calculation, the neutron sources for different burnups within the fuel rods were taken from previous calculations. The results are shown in Table IV. From the table, the system multiplication factor is rather constant (standard deviation 
TABLE III

RELATIVE FLUX CONTRIBUTION TO PASSIVE NEUTRON ASSAY EROM DIFFERENT EUEL PIN ROWS

THERMAL FLUX ALONG MIDPLANE NORMAL

\begin{tabular}{lrrrrrrr} 
Position* & 5 & 7.5 & 10 & 12.5 & 15 & 17.5 & 20 \\
\hline Pin Row & & & & & & & \\
\hline 1 & .95 & 1.20 & .95 & 1.07 & .86 & .79 & .83 \\
2,3 & 1.00 & .92 & 1.16 & 1.05 & 1.17 & 1.01 & 1.04 \\
4.5 & 1.72 & 1.08 & 1.84 & 1.87 & 1.79 & 1.75 & 1.01 \\
6.7 & $\frac{1.23}{.21}$ & $\frac{.95}{.13}$ & $\frac{1.06}{.14}$ & $\frac{1.08}{.099}$ & $\frac{1.11}{.19}$ & $\frac{1.22}{.22}$ & $\frac{.99}{.094}$
\end{tabular}

FAST FLUX $\left(1 \times 10^{-4}\right.$ to $\left.1.3 \mathrm{MeV}\right)$ ALONG MIDPLAIE NORMAL

\begin{tabular}{|c|c|c|c|c|c|c|c|}
\hline Position* & 5 & 7.5 & 10 & 12.5 & 15 & 17.5 & 20 \\
\hline \multicolumn{8}{|l|}{ Pin Row } \\
\hline $\begin{array}{l}1 \\
2,3 \\
4,5 \\
6,7 \\
5.1\end{array}$ & $\begin{array}{r}1.05 \\
1.14 \\
.86 \\
1.00 \\
.12\end{array}$ & $\begin{array}{r}1.20 \\
.92 \\
.98 \\
.94 \\
.13\end{array}$ & $\begin{array}{r}.96 \\
1.03 \\
1.09 \\
.91 \\
.079\end{array}$ & $\begin{array}{l}1.16 \\
1.00 \\
1.02 \\
.97 \\
.084\end{array}$ & $\begin{array}{r}.88 \\
.86 \\
.99 \\
1.09 \\
.11\end{array}$ & $\begin{array}{r}.97 \\
.92 \\
1.18 \\
.89 \\
.13\end{array}$ & $\begin{array}{r}.87 \\
1.00 \\
.95 \\
1.05 \\
.068\end{array}$ \\
\hline
\end{tabular}

\section{TRERMAL FLUX ALONG MIDPLANE DIAGONAL}

\begin{tabular}{|c|c|c|c|c|c|c|c|}
\hline Position* & 0 & 2.5 & 5 & 7.5 & 10 & 12.5 & 15 \\
\hline \multicolumn{8}{|l|}{ Pin Row } \\
\hline \multirow[t]{2}{*}{$\begin{array}{l}\frac{1}{2}, 3 \\
4,5 \\
5,7 \\
S . D\end{array}$} & $\begin{array}{r}.92 \\
.85 \\
.69 \\
1.33 \\
.29\end{array}$ & $\begin{array}{l}.86 \\
.88 \\
1.03 \\
1.04 \\
.097\end{array}$ & $\begin{array}{r}.84 \\
1.00 \\
.90 \\
1.09 \\
.11\end{array}$ & $\begin{array}{r}.85 \\
.95 \\
1.09 \\
.96 \\
.098\end{array}$ & $\begin{array}{r}.88 \\
.80 \\
1.06 \\
1.06 \\
.13\end{array}$ & $\begin{array}{r}.94 \\
.80 \\
i .14 \\
.99 \\
.14\end{array}$ & $\begin{array}{r}.98 \\
.84 \\
.97 \\
1.09 \\
.10\end{array}$ \\
\hline & FAST & FLUX $\left(1 \times 10^{-4}\right.$ & 1 to 1.3 & MeV) ALONG & MIDPLANE & DI.AGONAL & \\
\hline Posieion* & 0 & 2.5 & 5 & 7.5 & 10 & 12.5 & 15 \\
\hline \multicolumn{8}{|l|}{ Pin Row } \\
\hline $\begin{array}{l}1 \\
2,3 \\
4,5 \\
6,7 \\
\frac{1}{S . D} .\end{array}$ & $\begin{array}{r}.81 \\
.80 \\
.96 \\
1.15 \\
.16\end{array}$ & $\begin{array}{r}.84 \\
.69 \\
1.53 \\
.72 \\
. .39\end{array}$ & $\begin{array}{r}.90 \\
.88 \\
.95 \\
1.10 \\
.099\end{array}$ & $\begin{array}{r}.96 \\
.79 \\
.94 \\
1.14 \\
.14\end{array}$ & $\begin{array}{r}.99 \\
.89 \\
1.10 \\
.97 \\
.087\end{array}$ & $\begin{array}{r}.91 \\
.79 \\
1.02 \\
1.10 \\
.14\end{array}$ & $\begin{array}{r}.96 \\
.75 \\
1.04 \\
1.08 \\
.15\end{array}$ \\
\hline
\end{tabular}

*Distance from the surface or corner of the assembly in $\mathrm{cm}$. 
1.88) with burnups ranging from 13000 to $27000 \mathrm{MWD} / \mathrm{MTU}$. This illustrates the multiplication factor is not significantly affected by isotopic differences over the range of burnup consicered. The multiplication factor is mainly a function of the fuel density within the rods, and the spatial distribution of the fuel rods in the assembly. If the purpose of the assay is to determine the consistency between burnup and neutron emission rate, the multiplication effect can be ignored.

\section{MEASUREMENT OF PASSIVE NEUTRONS FROM IRRADIATED FUEL}

We have performed two separate passive neutron measurements of irradiated fuels: a BWR facility and a PWR facility. The $B i R$ has a power rating of 63 MWe and has been in operation since 1962. The PWR has a power rating of 1100 WWe and has been in operation since 1973.

\section{A. Response Versus Distance}

At the BWR facility, we have measured the neutron response as the detector-to-assembly distance was increased. The detector, a rission chamber containing $58 \mathrm{mg}{ }^{235} \mathrm{U}$ deposit, was submerged in a tube at approximately the midplane of an assembly. The electronics used consisted of an amplifier, a discriminator with the discrimination level set above the alpha signals, and a scaler. The spent fuel assembly, BRP-6, has a declared burnup of $17814 \mathrm{MWD} / \mathrm{MTU}$ and a cooling time of 842 days. The detector position was fixed with the spent fuel assembly being moved.

The resuits, together with the calculated values for thermal neutrons, are shown in Fig. 7. The calculated neutron count at a distance of $12 \mathrm{~cm}$ was normalized to the measured value. The calculated precisions ranged from 6 to $9 \%$. It is observed that for thermal neutrons, the measured diffusion length of $4.3 \mathrm{~cm}$ 
agrees well with the calculation. In general, the passive thermal neutron counting rate decreases by an order of magnitude when the detector-assembly distance is increased by $10 \mathrm{~cm}$. In Fig. 7 the relative response from an air ion chamber measured on the same assembly was also shown. In comparison, the ionisation chamber signal reduces by a factor of ten when the distanjee is increased by $\sim 30 \mathrm{~cm}$. These results illustrate that the passive neutron signal has a shorter range in water than the ionization chamber assay and also that the neutron contribution from the $(\gamma, n)$ reaction on water (or other low -2 material in the pool) is negligible compared with the neutrons emitted from the spent fuel. The results also show that fission chambers are insensitive to gamma radiations.

B. Neutron Emission Rate Versus Burnup

At the BWR facility, we have measured the neutron emission rate from six spent fuel assemblies with burnups ranging from 4356 to 18804 MWD/MiTU. The measurements were performed with a $58-\mathrm{mg}{ }^{235} \mathrm{U}$ fission chamber located in a tube placed $\sim 27 \mathrm{~cm}$ from the midplane of the assembly. The neutron counting rates for various burnups are listed in Table $V$ and also shown in $F$ ig.

\section{TABLE V}

PASSIVE NEUTRON ASSAY OF

BOILING WATER REACTOR SPENT ASSEMBLIES

\begin{tabular}{cccc} 
Assembly & $\begin{array}{c}\text { Burnup } \\
\text { (MWD/MTU) }\end{array}$ & $\begin{array}{c}\text { Cooling Time } \\
\text { (Days) }\end{array}$ & $\begin{array}{c}\text { Counting Rate } \\
\text { (cps) }\end{array}$ \\
\hline BWR 1 & 4356 & 842 & $.038 \pm .010$ \\
BWR 2 & 8883 & 1452 & $.373 \pm .031$ \\
BWR 3 & 13332 & 843 & $.981 \pm .037$ \\
BWR 4 & 15264 & 843 & $3.296 \pm .069$ \\
BWR 5 & 17122 & 844 & $4.064 \pm .076$ \\
BWR 6 & 17814 & 842 & $4.125 \pm .102$
\end{tabular}


8. Tound that the passive neutron counting rate is proporrional to b:rnup raised to 3.38 power. No cooling time correction has been made because all the assemblies had long and sirnilar cooling times.

We have also performed axial scans of ERP spent fuels with fission chamber. Since we found that the neutron emission rate is proportional to (burnup) ${ }^{3.38}$, the (neutron emission rate) $1 / 3.38$ should then be proportional to burnup. The axial neutron scan can then be compared with the axial gamma scan using the Ge detector. Figure 9 shows such a comparison. We
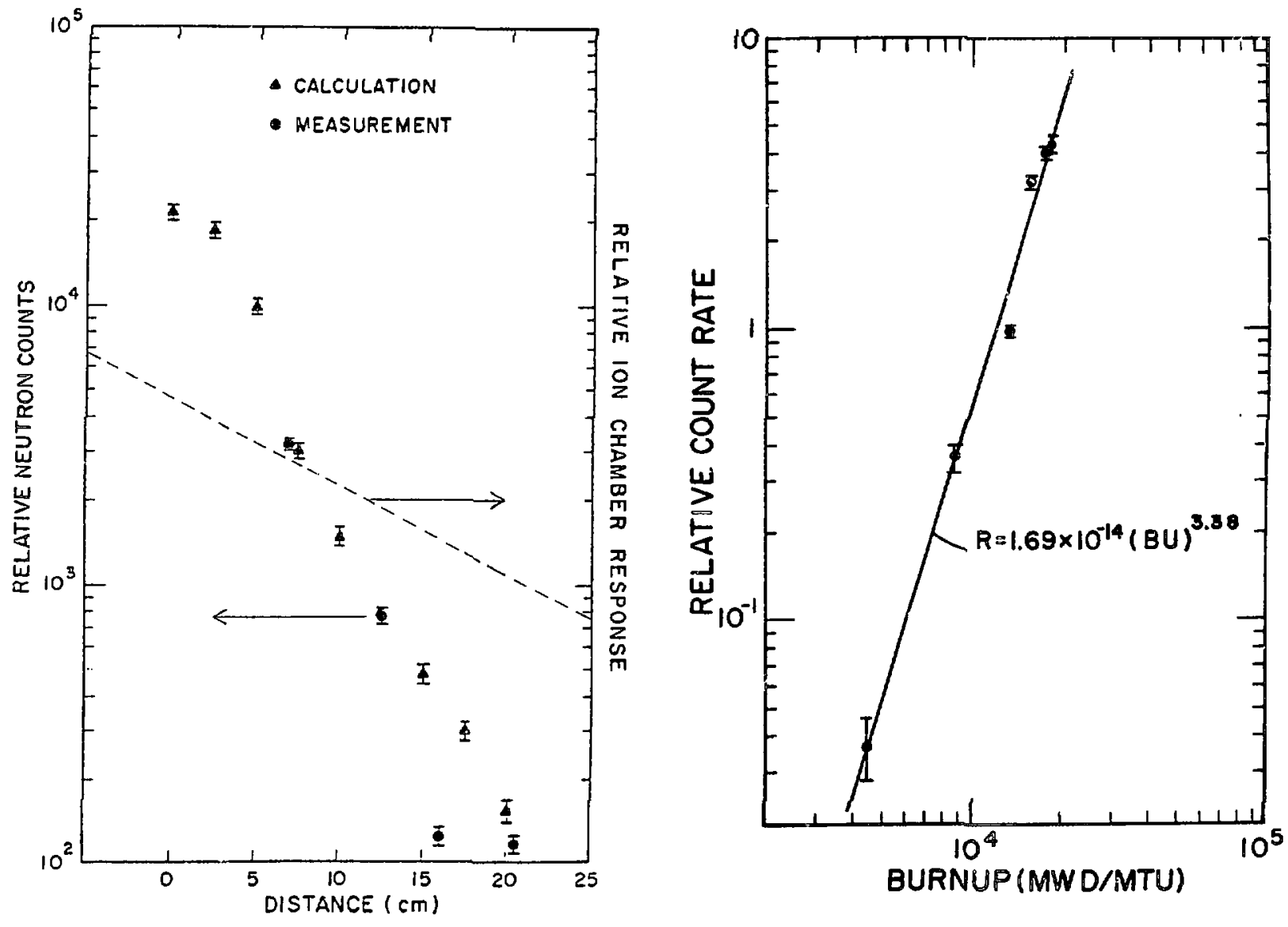

Fig. 7.

Comparison of the measured and calculated relative thermal neutron response as a function of increasing detector-to-assembly distance.

Fig. 8 .

Relative fission chamber response versus burnup for six spent fuel. assemblies from a BWR. 
found that the neutron and gamma scan agree well, supporting further that the neutron emission rate is proportional to burnup raised to 3.38 power.

Because the neutron count rate at the BWR exercise was relatively low (maximum counting rate $4 \mathrm{cps}$ ), for the PWR exercise we used a fission chamber with higher ${ }^{235_{\mathrm{U}}}$ loading (135 mg) and the chamber was placed closer to the assemblies than the previous exercise $(12 \mathrm{~cm}$ from midplane). The neutron counts for a $300 \mathrm{~s}$ assay on 9 assemblies is shown in Table VI and Fig. 10. The error bars of the PWR measurement are smaller than the data points. We found that the fission chamber counting rates are ali proportional to burnup raised to the 3.35 power. A cooling time correction has not been made. To make the cooling

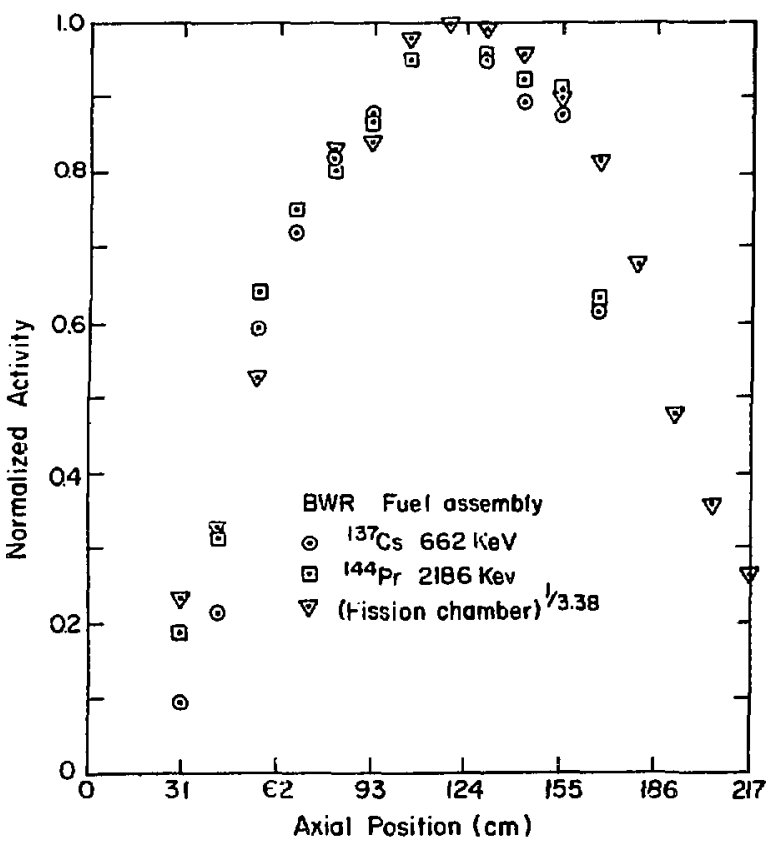

Fig. 9.

Axial profile of fission chamber response raised to $1 / 3.38$ power compared with $13{ }^{7} \mathrm{Cs}$ and ${ }^{14} \mathrm{P} \mathrm{Pr}$ activity profile.

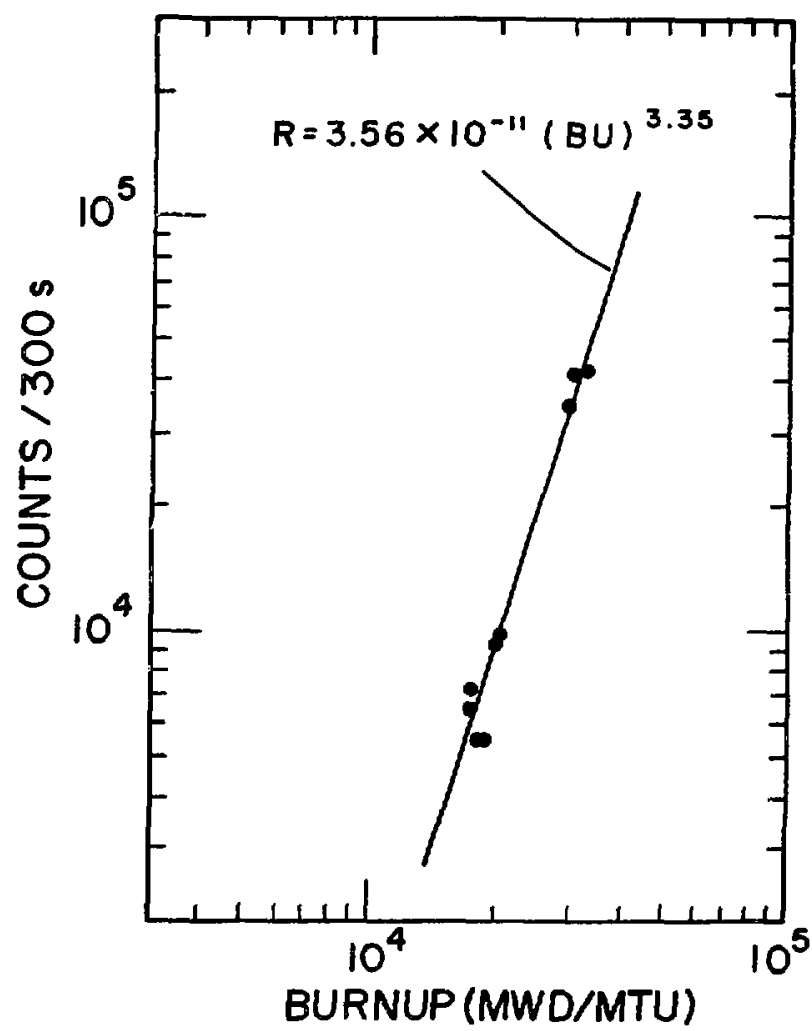

Fig. 10 .

Relative fission chamber response versus burnup for nine spent fuel assemblies from a PWR. 
TABIE VI

\section{PWR SPENT ASSEMBLIES \\ MEASURED BY PASSIVE NEUTRON ASSAY}

\begin{tabular}{cccc} 
Assembly & $\begin{array}{c}\text { Burnup } \\
\text { (MWD/MTU) }\end{array}$ & $\begin{array}{c}\text { Cooling Time } \\
\text { (Days) }\end{array}$ & Counts/300 s \\
\hline FWR 1 & 17404 & 528 & 7195 \\
PWR 2 & 17776 & 832 & 6493 \\
PWR 3 & 18279 & 528 & 5569 \\
PWR 4 & 18723 & 837 & 5501 \\
PWR 5 & 20066 & 527 & 9361 \\
PWR 6 & 20252 & 527 & 9754 \\
PWR 7 & 29129 & 140 & 36255 \\
PWR 8 & 31.851 & 279 & 41292 \\
PWR 9 & 32185 & 279 & 41436
\end{tabular}

correction, it is necessary to know the curium isotopic ratio for burnups ranging from 17000 to 32000 MWD/MTU. Although we have some indications of this isotopic ratio up to a burnup of $27000 \mathrm{MWD} / \mathrm{MTU}$ for Trino reactor fuel, we do not know the curium buildup beyond this burnup.

\section{CONCLUS IONS}

The agreement of the counting rate dependency on burnup between the two exercises is rather surprising since a boiling water reactor and a pressurized water reactor may have rather different actinide buildup. This agreement may be incidental; however, the results indicate that the passive neutron assay is a useful technique to determine consistency of burnups between assemblies.

Several salient features of passive neutron assay emerge from our study.

1. Passive neutron assay uses simple room-temperature detector (fission chamber) requiring no liquid nitrogen as in $\mathrm{Ge}$ 
detectors. The simplicity of the assay electronics (amplifier, discriminator, and scaler) enhances the reliability of apparatus. The measurement and data processing are straightforward.

2. Passive neutrons are more penetracing than gamma rays. The inner rods of an assembly can be detected in neutron assay.

3. A possible diversion scenario is the substitution of the spent fuel assembly with, for example, ${ }^{60}$ co rods, which can be easily produced in a reactor. Such a diversion can be easily detected by passive neutron assay since the activated rod has no neutron signal.

4. The neutron counting rate is reasonable and can be easily increased by reducing the assembly-detector distance.

While our study indicates that passive neutron assay is a useful assay technique and can well compliment the gamma assay of spent fuels, further investigations will clarify the nature of passive neutron assay: (1) the effect of cooling time on the neutron signals, and (2) investigate detectors other than fission chamber that can be used in passive neutron assay. Fission chambers contain fissile material. This may cause difficulty in shipping because of legal problems.

\section{ACKNOWLEDGMENTS}

We would like to express our thanks to R. Voll, H. Brazydlo, L. Monshor of Consumers Power Co., and D. O'Boyle, G. Perdikis, D. Walden, and M. Peterson of Commonweaith Edison for their help in the experimental portion of this study. The design and installation of apparatus by $S$. Beach of LASL Group $Q-1$ is also appreciated.

\section{REFERENCES}

1. T. N. Dragnev, "Experimental Techniques for Measuring Burn-up Nondestructive Techniques: Gamma Spectroscopy," International. Atomic Energy Agency report IAEA/STR-48 loctober 1970;.

2. S. T. Hsue, T. W. Crane, W. L. Talbert, and J. C. Lee, "Nondestructive Assay Methods for Irradiated Fuels," Los Alamos Scientific Laboratory report LA-6923 (January 1978). 
3. S. T. Hsue, "Methods for the Nondestructive Assay of Irradiated Fuels for Safeguards," Atomic Energy Review 16, No. 1 , 89-128 (1978).

4. "Advisory Group Meeting on the Nondestructive Anaiysis of Irradiated Power Reactor Fue?," International Atom ic Energy Agency report AG-11 (April 1977).

5. S. T. Hsue, "Fassive Neutron Assay of Irradiated Fuel," Los Alamos Scientific Laboratory report LA-6849-PR (August 1977).

6. J. E. Stewart, S. T. Hsue, and K. Kaieda, "The Neutron Assay of Spent PWR Fuel Assemblies," to be published in a Los Alamos Scientific Laboratory progress report.

7. S. T. Hsue, K. Kaieda, J. E. Stewart, and J. K. HaJbig, "The Neutron Assay of Spent Fuel Assemblies," to be pub shed in a Los Alamos Scientific Laboratory progress rejort.

8. P. Barbero, G. Bidoglio, M. Bresesti, R. Chevalier, D. D'Adamo, S. Facchetti, A. Federici, G. Guzzi, L. Lezzoli, F. Mannone, F. Marell, P. R. Trincherini, G. Buscaglia, A. Drago, R. Faccelli, A. Frigo, E. Ghezzi, R. Klersy, K. H. Schrader, A. Schuerenkaemper, R. Dierckx, J. Biteau, G。 cottone, A. Cricchio, L. Koch, R. Bannella, M. Paoletti Gualandi, and P. Peroni, "Post Irradiation Examination of the Fuel Discharged From the Trino Vercellese Reactor After the 2nd Irradiation Cycle," Joint Nuclear Research Centre (Ispra and Karlsruhe) and Ente Nazionale for l'Energie Electtrica-Rome (Italy) report EUR-5605e (1976).

9. Personal communication from M. Bresesti, Joint Nuclear Research Centre (Ispra, Italy) 1977.

10. "MCNP - A General Monte Carlo Code for Neutron and Photon Transport," Los Alamos Scientific Laboratory report LA-7396-M (July 1978). 